\title{
The unusual case of a renal
} urolith in a Mara (Dolichotis patagonum, Zimmermann 1780) in captivity

Andreia Garcês*, Paula Rodrigues, Carla Monteiro and Isabel Pires

\section{Abstract}

The mara (Dolichotis patagonum) is a large rodent originating from Argentina, and is frequently kept in zoos worldwide. Little is known about their diseases, particularly those affecting the urinary system. In this report, the authors describe a case of renal and urethral bilateral lithiasis. The aetiology of urolith formation is multifactorial, with the factors age, gender, urinary infections, diet, and urine $\mathrm{pH}$ contributing to the development of this pathology. This case is a contribution to alert for the diseases and metabolic disorders that can affect these animals.

Key words: urolith formation; Dolichotis patagonum; rodent; calculus; kidney

\section{Introduction}

Mara (Dolichotis patagonum) is a large, digitigrade, monogamous rodent of the family Caviidae native to Argentina (Campos et al., 2001; Fensome and Mathews, 2016). This species has been categorised as Near Threatened in the IUCN Red List of Endangered Species (Roach, 2016). Although they are often kept in zoo collections worldwide, there is little information available about their diseases (Batard and Lahitte, 2009).

\section{Case}

The cadaver of an adult female was sent from the Zoo Santo Inácio (Avintes,

Portugal), for post mortem examination at the Necropsy Service at the University of Trás-os-Montes and Alto Douro (Vila Real, Portugal) to determine the cause of death. At external examination, ulcers on the left hind limb and pale mucous membranes were observed. Internal examination, hemopericardium (about $5 \mathrm{~mL}$ ), pulmonary oedema, congestive hepatomegaly and intestinal tympanism were detected. The kidneys were of different size, the right was larger $(5 \mathrm{x}$ $4 \mathrm{~cm})$ and the left was smaller $(3 \times 2.5$ $\mathrm{cm}$ ) (Fig.1). At renal section, the right kidney showed dilation of the renal pelvis, with medullar atrophy (Fig

Andreia GARCÊS*, DVM, MSc, PhD Inno - Serviços Veterinários, Portugal (Corresponding author: andreiamvg@gmail.com), Paula RODRIGUES, DVM, MSc, PhD Auxiliar Professor University of Trás-osMontes and Alto Douro Portugal, Carla MONTEIRO, DVM, MSc, Zoo Santo Inácio, Portugal, Isabel PIRES, DVM, MSc, PhD Auxiliar Professor University of Trás-os-Montes and Alto Douro, Portugal 
2A). In the left kidney, the pelvis was dilated with the presence of a yellow, irregularly contoured calculus, $1 \mathrm{~cm}$ in major diameter (Fig 2B). The right ureter

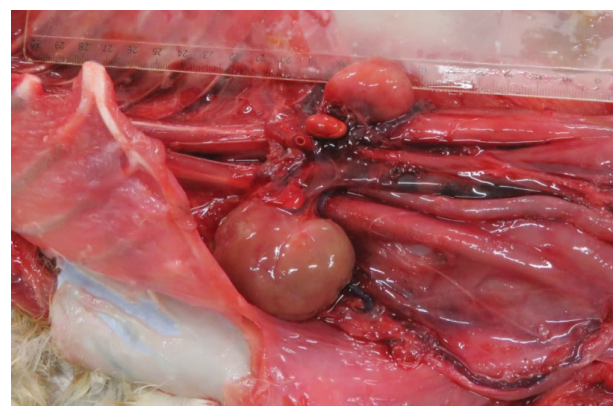

Figure 1. The kidneys presented different sizes, the right was larger $15 \times 4 \mathrm{~cm}$ and the left smaller $(3 \times 2.5 \mathrm{~cm})$ was dilated in all its extension, with the presence of calculus of $1 \mathrm{~cm}$ with yellow colouration (Fig 3). The final diagnosis was renal and urethral lithiasis, with hydronephrosis of the right kidney.

\section{Discussion}

In D. patagonum, trauma is the most common cause of death. Pseudotuberculosis, poxvirus and histoplasmosis are some of the infectious diseases most commonly described in these animals in captivity (Batard and Lahitte, 2009). The few reports of pathology affecting the urinary tract on maras are related to a segmental aplasia of the left ureter with severe secondary unilateral hydronephrosis in a mara

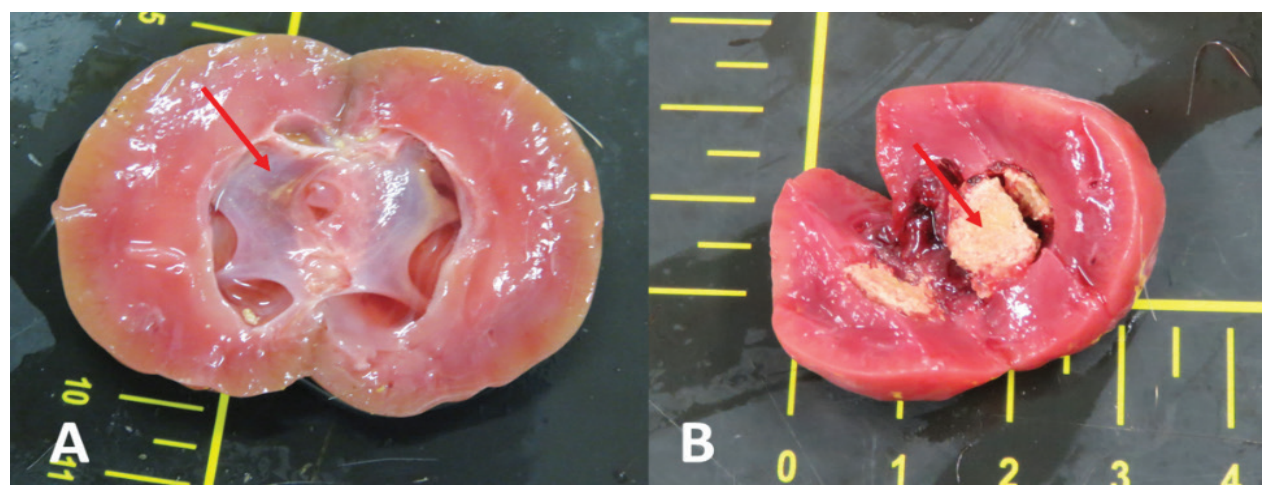

Figure 2. Upon section, the right kidney $(A)$ showed dilation of the renal pelvis, with medullar atrophy. In the left kidney $(B)$, the pelvis was dilated with presence and a yellow, irregularly contoured calculus, $1 \mathrm{~cm}$ diameter

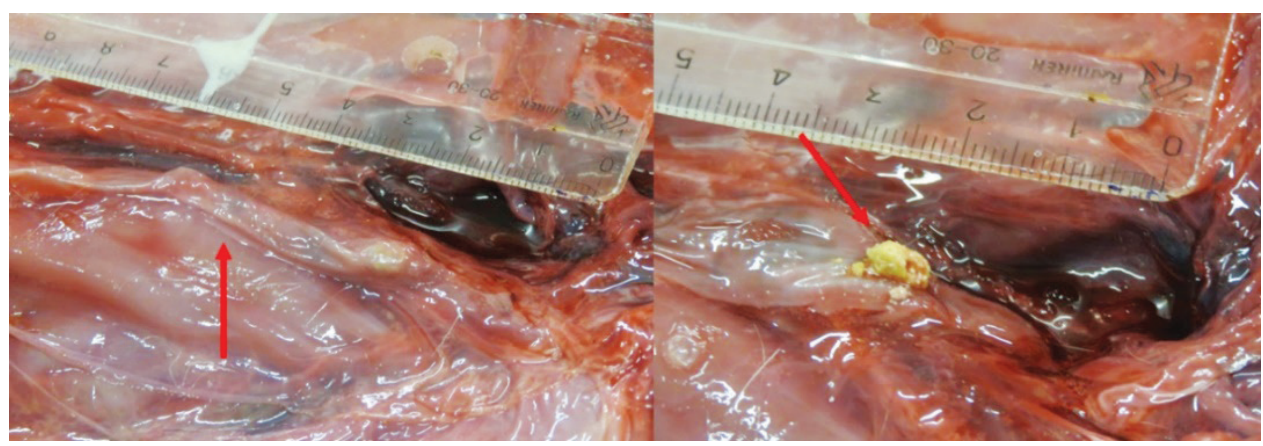

Figure 3. The right ureter was dilated in all its extension with the presence of a calculus of $1 \mathrm{~cm}$ with yellow colouration 
that died of trauma, described by RosasRosas et al. (2006). This is the first report of renal and urethral lithiasis, with hydronephrosis on a $D$. patagonum.

Unfortunately, it was not possible to determine the composition of calculi. Based on descriptions in domestic rodents, they may consist of calcium salts (Reavill and Lennox, 2020). The aetiology of urolith formation is multifactorial, where species, age, gender, anatomical or functional abnormalities of the urinary tract, metabolic abnormalities, urinary infections, diet, and urine $\mathrm{pH}$ are among the causative factors (Maxie, 2015). This pathology is very common in domestic animals, particularly in cats (Maxie, 2015; Zachary, 2016). Base on the information available, we can hypothesise that urolith development was associated with age or diet since the animal was held in captivity, and also could have had previously undetected urinary infections. This case likely started as unilateral urethritis were the only clinical signal were pain, which can be difficult to detect in these animals since they live in groups and can be very shy (Campos et al., 2001). With the development of the disease, ureteral obstruction resulted in hydronephrosis with loss of function of the ipsilateral kidney, while renal lithiasis developed on the other kidney. At the time of death, more than two-thirds of the total functional renal parenchyma was lost and the animal developed renal failure.

This case, although presented with some limitations, is an important contribution to understanding the diseases that can affect these animals and can contribute to the future monitoring of these diseases in zoos.

\section{References}

1. BATARD, A. and J. D. LAHITTE (2009): Pathologie du mara (Dolichotis patagonun). Revue Méd. Vét. 160, 308-313.

2. CAMPOS, C. M., M. F. TOGNELLI and R. A. OJEDA (2001): Dolichotis patagonum. Mam. Species. 652, 1-5.

3. FENSOME, A. G. and F. MATHEWS (2016): Roads and bats: a meta-analysis and review of the evidence on vehicle collisions and barrier effects. Mammal Rev. 46, 311-323.

4. MAXIE, M. G. (2015): Jubb, Kennedy, and Palmer's pathology of domestic animals volume 3. Chicago: Saunders Ltd.

5. REAVILL, D. and A. LENNOX (2020): Disease Overview of the Urinary Tract in Exotic Companion Mammals and Tips on Clinical Management Drury. Vet Clin Exot Anim, 23(January), 169-193.

6. ROACH, N. (2016): Dolichotis patagonum. The IUCN Red List of Threatened Species 2016: E.T6785A22190337. http://dx.doi.org/10.2305/ IUCN.UK.2016-2.RLTS.T6785A22190337.en

7. ROSAS-ROSAS, A. G., C. JUAN-SALLÉS and M. M. GARNER (2006): Pathological findings in a captive colony of maras (Dolichotis patagonum). Vet. Rec. $158,727-731$.

8. ZACHARY, J. F. (2016): Pathologic basis of veterinary disease. Chicago: Mosby.

\section{Neobični slučaj bubrežnog kamenca u mare (Dolichotis patagonum, Zimmermann 1780.) u zatočeništvu}

Andreia GARCÊS, DVM, MSc, PhD Inno-Serviços Veterinários, Portugal, Paula RODRIGUES, DVM, MSc, PhD Auxiliar Professor University of Trás-os-Montes and Alto Douro Portugal, Carla MONTEIRO, DVM, MSc, Zoo Santo Inácio, Portugal, Isabel PIRES, DVM, MSc, PhD Auxiliar Professor University of Trás-os-Montes and Alto Douro, Portugal

Mare (Dolichotis patagonum) su veliki glodavci podrijetlom iz Argentine koji su česti stanovnici zooloških vrtova diljem svijeta. Ipak, malo je toga poznato o njihovim bolestima, posebice onima koje utječu na mokraćni sustav. U ovom radu autori opisuju slučaj obostrane formacije bubrežnih i uretralnih kamenaca. Na etiologiju formiranja kamenca utječe više čimbenika, s tim da su dob, spol, urinarne infekcije, prehrana i $\mathrm{pH}$ urina neki od čimbenika koji doprinose razvoju ove patologije. Ovaj članak predstavlja doprinos upozorenju na bolesti i metaboličke poremećaje koji mogu pogoditi ove životinje.

Ključne riječi: formacija urolita, Dolichotis patagonum, glodavac, kamenac, bubreg 